\title{
Evaluasi Sistem Akuntansi Penerimaan dan Pengeluaran Kas pada PT. Alfa Global Indonesia
}

\author{
Rostiaty Yunus \\ Sekolah Tinggi Ilmu Ekonomi YPUP Makassar \\ rostiatyyunus@gmail.com
}

\begin{tabular}{l}
\hline ARTICLEDETAILS \\
\hline History \\
Received : February \\
Revised Format : March \\
Accepted : April \\
\hline
\end{tabular}

Keywords :

accountancy system, cash flow accountancy system.

\begin{abstract}
S
This research aimed to find out the implementation of system of cash flow accountancy at PT. Alfa Global Indonesia. The design of this research was done to analyze the system of cash flow accountancy at PT. Alfa Global Indonesia. The method used was descriptive qualitative to describe the theory of accountancy cash flow system at PT. Alfa Global Indonesia. The result of this research indicated cash flow accountancy system at PT. Alfa Global Indonesia was done well. The system used was more accurate and the information released was very supporting to make decision.
\end{abstract}

\section{PENDAHULUAN}

Pertumbuhan ekonomi dan perkembangan dunia bisnis pada zaman globalisasi menuntut seluruh perusahaan untuk memperoleh keuntungan yang maksimal. Maka Indonesia harus mampu bersaing dengan negara-negara lain terutama dalam system informasi akuntansi yang dipergunakan secara efektif dan efisien. Penanganan dalam hal pengeluaran kas merupakan suatu aktifitas dalam perusahaan yang tidak mungkin dapat dipisahkan. Pada perusahaan haruslah berhati-hati dalam melakukan aktifitas yang berhubungan pengeluaran kas, artinya setiap pengeluaran kas yang dilakukan harus diperhitungkan manfaat dan keuntungan yang akan didapat. Untuk mendapatkan hasil yang maksimal, maka setiap sperusahaan wajib memiliki kualitas akuntansi yang baik dari segi Pendidikan, keahlian maupun keterampilan dalam melaksanakan tugasnya. Pengeluaran kas harus dilakukan secara efektif adan efisien agar tidak terjadi pemborosan anggaran. Oleh karena itu diperlukan sebuah system yang memadai untuk dapat mengawasi pengeluaran kas. Dilaksanakan dengan kas kecil yang diselenggarakan dengan salah satu system saldo berfluktuasi (fluctuating fund balancing system) dan system saldo tetap (imprestsistem).

Pengertian lain, sistem akuntansi pengeluaran kas merupakan sistem yang digunakan untuk mencatat seIuruh transaksi pengeluaran kas, yang meliputi serangkaian proses kegiatan menerima, menyimpan, menyetor, membayar, menyerahkan dan mempertanggungjawabkan pengeluaran uang yang berada dalam pengelolaan suatu perusahaan. Sistem akuntansi pengeluaran kas terdiri dari dua sistem pokok, yaitu sistem akuntansi pengeluaran kas dengan cek dan sistem pengeluaran kas dengan uang tunai melalui sistem dana kas kecil.

Penerapan sebuah system akuntansi dalam suatu perusahaan untuk menangani dan mengatur jalannya semua aktifitas perusahaan baik yang bersifat operasional maupun non operasional sangatlah penting. Dengan adanya penerapan system akuntansi dalam perusahaan diharapkan semua aktivitas perusahaan dapat berjalan dengan baik terutama yang berkaitan erat dengan lajunya arus kas yaitu arus kas masuk dan arus kas keluar. Hampir seiap transaksi keuangan selalu mempengaruhi saldo kas. Dikarenakan sifat kas yang mudah untuk digelapkan atau diselewengkan maka perlu adanya suatu system akuntansi yang sesuai agar pelaksanaan 
dan penggunaan uang kas benar-benar digunakan untuk pembiayaan pengeluaran. perusahaan.Sistem akuntansi tersebut adalah sistem akuntansi pengeluaran kas.

Menurut Mahsina (2018) diperlukan sebuah sistem informasi akuntansi yang memperjelas bagaimana suatu prosedur harus dibuat sehingga bisa diketahui bagaimana proses penerimaan pendapatan pada saat penerimaan pembayaran dari kontrak pekerjaan yang dilakukan sampai data pembayaran tersebut masuk ke bagian accounting, serta prosedur yang harus dibuat untuk pengeluaran kas yang digunakan untuk kegiatan operasional perusahaan sehari-hari untuk mencapai tujuan perusahaan sesuai dengan perencanaan awal dan menghasilkan output yang baik.

Penerapan system skuntansi pengeluaran kas yang baik dalam perusahaan mempunyai beberapa manfaat penting. Manfaat tersebut antara lain adalah mengefektifkan biaya-biaya yang dikeluarkan perusahaan, mencegah terjadinya penyalahgunaan, penyelewengan dan penggela[an uang kas serta membantu perusahaan dalam memprediksi penentuan besarnya anggaran yang harus tersedia untuk periode mendatang. Menurut Badriwan dalam (Tanjung 2017) menambahkan bahwa beberapa prosedur pengawasan terhadap pengeluaran kas yang penting adalah sebagai berikut : 1) Semua pengeluaran menggunakan cek kecuali untuk pengeluaran yang kecil. 2) dibentuk kas kecil yang diawasi dengan ketat. 3) pelulusan cek hanya dilakukan jima didukung oleh bukti-bukti yang lengkap. 4) Dipisahkan antara orang yang mengumpulkan bukti-bukti pengeluaran yang menulis cek, yang menandatangani cek dan yang mencatat penerimaan kas. 5) Diadakan pemeriksaan intern dalam waktu tak tentu dan diharuskan membuat laporan kas harian

PT. Alfa Global Indonesia adalah agen tunggal pemegang motor serbaguna Nozomi di Indonesia yang membuka dealer Motor serba guna di jalan Karaeng Makkawari. Hal tersebut mengharuskan perusahaan ini untuk mempunyai suatu sistem akuntansi yang baik karena banyaknya transaksi penjualan yang menimbulkan adanya penerimaan kas dan operasi perusahaan yang menimbulkan pengeluaran-pengeluaran kas maka sistem yang ada haruslah berjalan dengan baik. Terutama dalam sistem akuntansi pengeluaran kas karena sifat kas yang likud dan mudah dicurangkan.

Alur transaksi pengeluaran kas pada PT Alfa Global Indonesia disertai dengan bukti transaksi digambarkan sebagai berikut: a) Alur pengeluaran kas dimulai dari transaksi pembelian tunai, pembayaran utang dan biaya-biaya lainnya. B) Menerima formulir permintaan barang atau jasa dan melampirkan bukti faktur pembelian yang diberikan oleh supplier untuk kemudian dicocokkan dengan bukti pembelian, apabila cocok maka akan diambil dan jika tidak sesuai maka dilakukan konfirmasi. C) melakukan pembaayaran atas dasar bukti pembelian barang atau jasa dengan cara transfer rekening atau memberikan cek.

Dengan alasan diatas maka mmendorong peneliti untuk mengadakan penelitian dengan judul "Evaluasi Sistem Akuntansi Pengeluaran Kas Pada PT AGI (Alfa Global Indonesia)"

Berdasarkan uraian mengenai latar belakang masalah yang telah dikemukakan sebelumnya, maka yang menjadi rumusan masalah penelitian ini yaitu "bagaimana penerapan system akuntansi pengeluaran kas yang diterapkan pada PT AGI (Alfa Global Indonesia)?”

Adapun tujuan penelitian adalah untuk mengetahui penerapan sistem akuntansi pengeluaran kas yang diterapkan PT AGI (Alfa Global Indonesia) 


\section{TINJAUAN LITERATUR}

Akuntansi diartikan sebagai proses mengidentifikasikan, mengukur, dan menyampaikan informasi ekonomi sebagai bahan informasi dalam hal mempertimbangkan berbagai alternatif dalam mengambil kesimpulan oleh para pemakaianya.

Akuntansi adalah seni pencatatan, penggolongan dan pengikhtisaran dengan cara tertentu dalam ukuran moneter transaksi dan kejadian-kejadian yang umumnya bersifat keuangan dan termasuk menafsirkan hasil-hasilnya (Harahap.S . S., 2015)

Syarifuddin (2019) menyatakan bahwa laporan keuangan merupakan ringkasan dari suatu proses pencatatan, dan transaksi-transaksi keuangan yang terjadi selama satu tahun buku yang bersangkutan.

Mulyadi (2016) Mengungkapkan bahwa sistem akuntansi adalah salah satu sistem informasi di antara berbagai sistem yang di gunakan oleh manajemen dalam mengelolah perusahaan.

Sistem akuntansi adalah organisasi formulir, catatan, dan laporan yang dikoordinasikan sedemikian rupa untuk menyediakan informasi keuangan yang dibutuhkan oleh manajemen guna untuk memunahkan pengelolaan perusahaan (Mulyadi 2016). adalah :

Adapun unsur-unsur sistem akuntansi menurut Mulyadi 2005 dalam (Tanjung 2018)

\section{Formulir}

Formulir merupakan dokumen yang digunakan untuk mencatat atau merekam kejadian transaksi.Di dalam formulir terdapat data transaksi yang dapat dijadikan dasar dalam pencatatan.

2. Jurnal

Jurnal merupakan sistem akuntansi yang dilakukan untuk mencatat, mengelompokkan transaksi sejenis, dan meringkas data keuangan lainnya.Hasil dari peringkasan data kemudian di-posting ke rekening yang bersangkutan di dalam buku besar. Bentuk Jurnal yang biasa digunakan adalah sebagai berikut: Jurnal Penerimaan Kas, jurnal yang disediakan khusus untuk mecatat transaksi penerimaan kas. Jurnal Pengeluaran Kas, jurnal yang khusus disediakan untuk mencatat segala jenis pengeluaran kas. Jurnal Pembelian, jurnal yang digunakan untuk mencatat pembelian secara kredit. Pembelian secara tunai masuk ke dalam jurnal pengeluaran kas. Jurnal Penjualan, jurnal yang disediakan khusus untuk mencatat transaksi penjualan secara kredit. Penjualan secara tunai dimasukkan dalam jurnal penerimaan kas.Jurnal Umum disediakan khusus untuk mencatat penyesuaian pembukuan, koreksi transaksi dan hal lain yang tidak dapat dicatat dalam jurnal khusus.

3. Buku Besar (General Ledger)

Buku besar terdiri dari kumpulan rekening-rekening yang berfungsi untuk meringkasdata keuangan yang telah dicatat sebelumnya dalam jurnal.Rekening buku besar dianggap juga sebagai tempat penggolongan data keuangan untuk penyajian laporan keuangan.

4. Buku Pembantu (Subsidiary Ledger)

Buku pembantu berisi rekening-rekening pembantu dalam merinci data keuangan, contohnya seperti mengelompokkan jenis transaksi yang terjadi di suatu perusahaan satu dengan yang lainnya. 


\section{Laporan}

Laporan adalah hasil akhir dari proses akuntansi, berupa neraca, laporan laba rugi, laporan perubahan modal, laporan biaya pemasaran, laporan harga pokok produksi, laporan harga pokok penjualan, daftar utang, daftar saldo persediaan.

Berdasarkan definisi di atas maka dapat dipahami bahwa sistem akuntansi adalah sebuah ikhtisar yang terdiri dari catatan manual atau komputerisasi transaksi keuangan untuk tujuan rekaman, mengkategorikan, menganalisis dan melaporkan informasi manajemen keuangan yang tepat waktu.Sistem akuntasi memiliki berbagai fungsi seperti mengumpulkan dan menyimpan data transaksi, memproses data menjadi informasi untuk pengambilan keputusan, dan sebagai control terhadap organisasi.

Kas adalah aktiva yang paling lancar disbanding aktiva lainnya, oleh sebab itu kas merupakan aktiva yang paling dimengerti untuk dicuri, dimanipulasi, dan diselewengkan (Hery, 2016)

Alasan menyediakan sejumlah kas, baik uang tunai yang ada dalam perusahaan atau yang ada pada bank (setiap saat bisa diambil sebagai uang tunai) adalah :

1. Kebutuhan untuk operasional dalam melakukan transaksi yang terjadi. Aliran kas masuk tidak sama dengan aliran kas keluar Dari beberapa pengertian diatas,dapat Sehingga diperlukan adanya kas untuk transaksi usaha, seperti pembayaran bahan baku, membayar upah atau gaji dan pembayaran lainnya yang harus dikeluarkan

2. Kebutuhan untuk selalu tersedia uang kas untuk berjaga-jaga dalam mengatasi pembayaran tak terduga yang harus dibayar sehinggga tidak mengganggu operasional perusahaan

3. Kebutuhan untuk memperoleh keuntungan dengan adanya perubahan harga yang menguntungkan dengan menjual surat berharga yang harganya naik

4. disimpulkan bahwa sistem akuntansi pengeluaran kas adalah suatu proses penanganan dan pengawasan terhadap pengeluaran uang kas perusahaan yang digunakan untuk pembelian tunai,pelunasan utang,dan pembayaran biaya-biaya atau kewajiban lainnya mulai dari keluarnya bukti kas keluar,pencatatan dan pelaporannya sampai dengan pengendalian intern yang diterapkan perusahaan untuk mengatur dan mengawasi jalannya aktifitas lainnya.

Menurut Esteria (2016), sistem akuntansi penerimaan kas adalah kas yang diterima perusahaan baikyang berupa uang tunai maupun surat-surat berharga yang mempunyai sifat dapat segera digunakan, yang berasal dari transaksi perusahaan maupun penjualan tunai, pelunasan piutang atau transaksi lainnya yang dapat menambah kas perusahaan.

Menurut Darsono dan Aripurwanti dalam Siagian (2018), Pengeluaran kas pada umumnya untuk membeli aktiva tetap, pembelian bahan baku, pembayaran upah tenaga kerja langsung, pembayaran biaya tidak langsung pabrik, pembayaran biaya pemasaran, pembayaran biaya umum dan administrasi, pembaran Bungan, pembayaran deviden.

Menurut Mulyadi (2010) dalam Nopi Kusmiyati (2018) Adapun fungsi yang terkait dalam sistem akuntansi pengeluaran kas dengan cek yaitu :

1. Fungsi yang memerlukan pengeluaran kas yaitu jika suatu fungsi pengeluaran kas (misalnya untuk pembelian jasa dan untuk biaya perjalanan dinas) fungsi yang bersangkutan mengajukan permintaan cek kepada fungsi akuntan (Bagian utang). Permintaan cek ini harus mendapatkan persetujuan dari kepala fungsi yang bersangkutan. Jika perusahaan menggunakan (voucher) untuk memungkinkan Bagian kas mengisi cek sejumlah permintaan yang diajukan oleh fungsi yang memerlukan pengeluaran kas.

2. Fungsi kas Yaitu dalam akuntansi pengeluaran kas dengan cek, fungsi ini berfungsi bertanggungjawab dalam mengisi cek, memintakan otorisasi atas cek, dan mengirimkan cek kepada kreditur via pos

3. fungsi akuntansi yang meiliki fungsi tanggungjawab atas pencatatan pengeluaran kas yang menyangkut biaya dan persediaan, pencatatan transaksi pengeluaran kas dalam jurnal pengeluaran kas dan pembuatas bukti kas keluar 
4. Fungsi pemeriksaan intern

Dokumen yang digunakan dalam system akuntansi dana kas kecil (Mulyadi,2016) adalah

a. Bukti kas keluar

Dokumen ini berfungsi sebagai perintah pengeluaran kas kepada bagian kasa sebesar yang tercantum dalam dokumen tersebut,dan dokumen ini jga berfungsi sebagai surat pemberitahuan (remittance advice) yang dikirim kepada kreditur dan berfunsi pula sebagai dokumen sumber bagi pencatatan berkurangnya utang.

b. Cek

Dari sudut sistem informasi akuntansi,cek merupakan dokumen yang digunakan Untuk memerintahkan bank melakukan pembayaran sejumlah kepada orang atau organisasi Namanya tercantum pada cek. Ada dua cek yang digunakan dalam pembayaran (1) check issuer membuat cek atas nama atau (2) membuat cek atas unjuk.

c. Permintaan cek (check request)

Dokumen ini berfungsi sebagai permintaan dari fungsi yang memerlukan pengeluaran kas kepada fungsi akuntansi untuk membuat bukti kas keluar yang tidak berupa pembayaran utang yang timbul dari transaksi pembelian

Catatan akuntansi yang dipergunakan dalam sistem akuntansipengeluaran kas dengan cek (Mulyadi,2016) adalah:

1. Jurnal pengeluaran kas (cash disbursement journal). Dalam pencatatan utang dengan account payable system untuk mencatat transaksi pembelian digunakan jurnal pembelian dan mencatat pengeluaran kas digunakan pengeluaran kas.

2. Register cek (check register). Dalam pencatatan utang dengan voucher payable system transaksi untuk mencatat transaksi pembelian digunakan dua jurnal register bukti kas keluar yang digunakan untuk mencatat uang yang timbul sedangkan register cek digunakan untuk memcatat cek-cek perusahaan yang dikeluarkan.

Fungsi yang terkait dalam system akuntansi pengeluaran kas denngan cek (Mulyadi 2016) adalah :

1. Fungsi kas

Fungsi kas bertanggung jawab dalam mengisi cek,memintakan otorisasi atas cek,dan menyerahkan cek kepada pemegang dana kas kecil pada saat pembentukan dana kas kecil dan pada saat pengisian kembali dana kas kecil.

2. Fungsi akuntansi

Fungsi akuntansi ini bertanggung jawab atas:

a. pencatatan pengeluaran kas kecil yang menyangkut beban dan persedian.

b. Pencatatan transaksi pembentukan dana kas kecil.

c. Pencatatan pengisian kembali dana kas kecil dalam jurnal pengeluaran kas register cek.

d. Pencatatan pengeluaran dana kas kecil dalam jurnal pengeluaran dana kas kecil.

e. Pembuatan bukti kas keluar yang memberikan otorisasi kepada fungsi dalam mengeluarkan cek sebesar yang tercantum dalam dokumen tersebut.

3. Fungsi pemegang dana kas kecil.

Fungsi ini bertanggung jawab atas penyimpanan dan pengeluaran dana kas kecil sesuai dengan otorisasi dari pejabat tertentu yang ditunjuk dan permintaan pengisian kembali dana kas kecil

4. Fungsi pemeriksaan intern

Fungsi ini bertanggung jaawab atas penghitung dana kas kecil secara periodic dan pencocokan hasil perhitungannya dalam pencatatan kas. 
Menurut Moeller dalam Muliasari (2012), penendalian internal adalah proses yang didimplementasikan oleh manajemen dan dirancang untuk memberikan keyakinan yang memadai lagi :

1. Laporan keuangan dan informasi operasional yang handal

2. Kepatuhan terhadap kebijakan prosedur, hukum, dan undang-undang

3. Perlindungan asset

4. Pencapaian fari misi dan tujuan yang sudah ditetapkan

5. Untegritas dan nilai-nilai etis

Menurut Coso Dalam Puspita (2015) mendefinisikan Sistem Penggendalian Intern adalah suatu proses yang dipengaruhi oleh dewan komisaris, manajemen dalam personil satuan usaha lainnya, yang dirancang untuk mendapat keyakinan memadai tentang pencapaian tujuan dalam hal-hal berikut :

1. Keandalan Pelaporan Keuangan.

2. Kesesuaian dengan Undang-Undang peraturan yang berlaku.

3. Efektifitas dan Efesiensi Operasi.

Menurut Mulyadi dalam Tanjung (2015) Tujuan sistem pengendalian intern :

1. Menjaga Kekayaan Organisasi

2. Mengcek ketelitian dan Keandalan data Akuntansi

3. Mendorong Efisiensi, dan

4. Mendorong dipatuhinya kebijakan manajemen

Menurut Diana dan Setiawan (2011) Dalam Sari (2014) flowchart merupakan informasi melalui proses dari input, output, sampai menjadi arsip dan digambarkan dengan grafis dari sistem informasi yang terkait.

Gambar.1. Flowchard

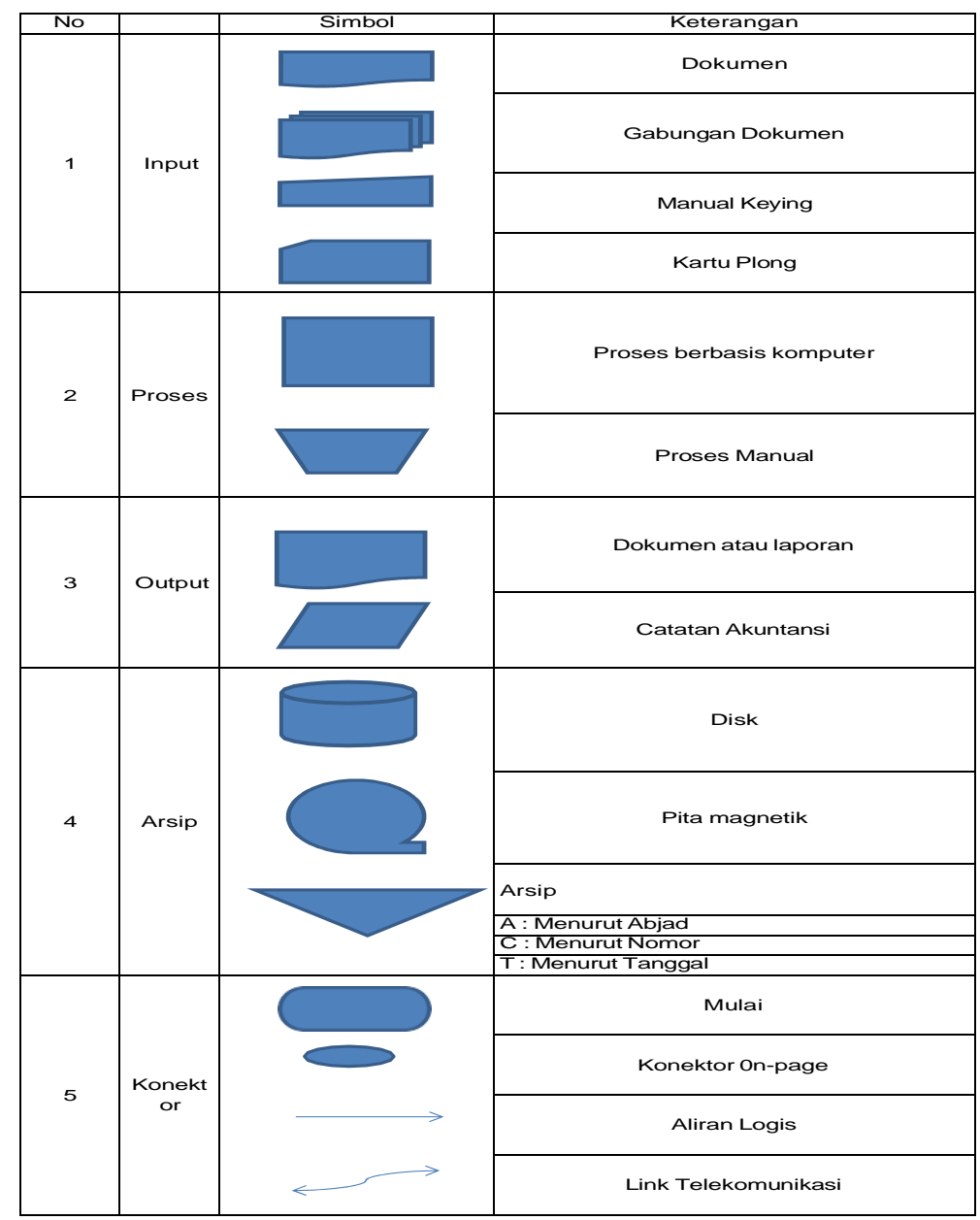




\section{METODE PENELITIAN}

Penelitian ini menggunakan metode kualitatif yaitu metode yang digunakan untuk meneliti pada kondisi objek yang alamiah, dimana penelitian adalah sebagai instrumen kunci, teknik pengumpulan data dilakukan secara gabungan, dan hasil penelitian lebih menekankan makna daripada generalisasi.

Penelitian ini dilaksanakan di PT Alfa Global Indonesia Makassar yang bergerak dibidang penjualan motor tiga roda, yang terletak di Jl. Krg Makkawari, Samata, Kec. Somba opu, Kab.Gowa. Adapun waktu penelitian yang direncanakan dilaksanakan kurang lebih (2 Bulan) dimulai dari Juni sampai dengan Agustus 2019.

Penelitian ini menggunakan jenis sumber data sebagai berikut : 1) Jenis data yaitu dalam penelitian ini jenis data yang digunakan adalah data kualitatif dengan melakukan penelitian lapangan. Penelitian kualitatif merupakan suatu strategi yang menekankan pencarian makna, pengertian, konsep, karakteristik, gejala, symbol, maupun deskripsi tentang fenomena, focus dan multimetode. Dengan tujuan untuk menemukan jawaban terhadap suatu fenomena melalui aplikasi prosedur ilmiah secara sistemastis. 2) Sumber data : a) Data primer diperoleh dari wawancara Bersama manajer bagian keuangan dan pihak terkait. B) data sekunder yang diperlukan antara lain gambaran umum mengenai PT Alfa Global Indonesia serta data lain yang berhubungan

Tehnik pengumpulan data yaitu: 1) Wawancara (interview) adalah suatu kejadian atau suatu proses interaksi antara pewawancara (interviewer) dan sumber informasi atau orang yang diwawancarai (interviewee) melalui komunikasi langsung. 2) Observasi, Penelitian ini melakukan observasi dengan mengamati langsung proses transaksi agar mendapatkan data yang objektif dan sistematis. 3) Studi Kepustakaan Yaitu teknik pengumpulan data dengan bukubuku, jurnal, dan literatur lain yang berhubungan dengan penelitian in. 4) Dokumentasi merupakan catatan atau karya seseorang tentang suatu yang sudah berlalu. Dokumen ini dapat berbentuk teks tertulis artifacs, gambar maupun foto

Analisis data merupakan tahapan penting dalam penelitian kualitatif. Analisis data merupakan suatu proses sistematis pencarian dan pengaturan transkip wawancara, observasi catatan lapangan dokumen, foto dan material lainnyauntuk meningkatkan pemahaman peneliti tentang data yang telah dikumpulkam, sehingga memungkinkan temuan penelitian dapat disajikan dan di informasikan kepada orang lain. Yang bertujuan untuk menggambarkan dan menerangkan fenomena atau situasi social yang diteliti.

\section{HASIL DAN PEMBAHASAN}

1. Sistem Akuntansi Penerimaan kas pada PT. Alfa Global Indonesia berasal dari penjualan tunai, penerimaan uang muka penjualan kredit, penerimaan dari servis kendaraan. Penerimaan kas terbesar para PT.Alfa Global Indonesia adalah penjualan kendaraan tiga roda. Penjualan tunai dilaksanakan dengan cara mewajibkan pembeli melakukan pembayaran harga kendaraan terlebih dahulu kepada bagian kasir sebelum kendaraan diserahkan oleh perusahaan kepada pembeli. Setelah uang diserahkan ke ke bagian kasir, kendaraan akan diperiksa untuk siap pakaian dan dikirim ke pelanggan. PT. Alfa Global Indonesia merancang sistem akuntansi penerimaan kas yang meliputi beberapa unsur penting antara lain adalah dokumen yang digunakan, fungsi yang terkait, pengendalian intern, dan bagian alur penerimaan kas.

a. Prosedur penerimaan kas

1) Penerimaan uang tunai dimulai dari terjadinya transaksi yang menyebabkan penerimaan kas seperti penjualan tunai, penerimaan pembayaran piutang, dan lainlain.

2) Memeriksa bukti transaksi yang dikeluarkan oleh coustemer service dengan teliti berdasarkan invoice dan faktur penjualannya. 
3) Menghitung jumlah transaksi dengan benar.

4) Menerima pembayaran dengan menghitung jumlah transaksi dengan benar.

5) Memeriksa keabsahan uang yang diterima dan bukti transfer yang diberikan. Gunakan alat untuk mengecek uang secara fisik.

6) Membuat bukti transaksi penerimaan kas seperti kuwitansi 3 rangkap (rangkap 1 coustomer, rangkap 2 kasir, dan rangkap 3 accounting).

b. Dokumen yang digunakan

Dokumen yang digunakan pada PT. Alfa Global Indonesia adalah SPK (surat pesanan kendaraan), kwitansi, SO (sales order).

c. Fungsi yang terkait

1. fungsi penjualan

2. fungsi kas

3. fungsi administrasi penjualan

4. fungsi gudang

2. fungsi keuangan Transaksi penerimaan kas pada PT. Alfa Global Indonesia

Gambar. 4.2

Flowchard Penerimaan kas PT. Alfa Global Indonesia

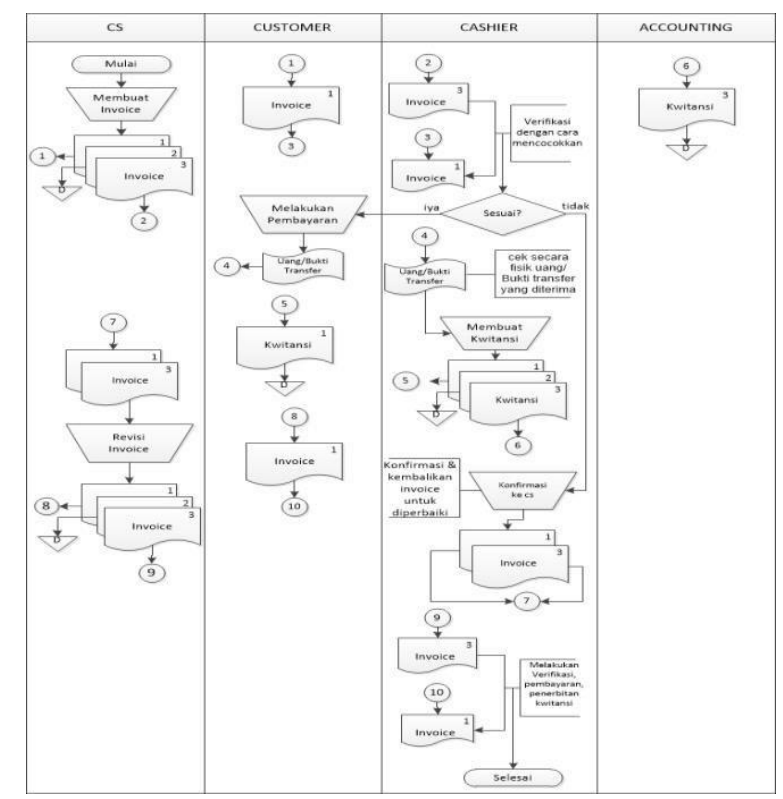

3. Sistem Akuntansi Penngeluaran Kas Pada Pt. Alfa Global Indonesia.

PT. Alfa Global Indonesia merancang sistem akuntansi pengeluaran kas yang meliputi beberapa unsur penting antara lain adalah dokemen yang digunakan,fungsi yang terkait, pengendalian intern, dan bagian alur pengeluaran kas.

a. Prosedur pengeluaran kas

i. Alur pengeluaran uang kas dimulai dari transaksi pembelian tunai, pembayaran utang, dan pembayaran biaya-biaya.

ii. Menerima formulir permintaan barang atau jasa dan melampirkan bukti invoice/faktur pembelian yang dibawah atau diberikan oleh supplier untuk kemudian dicocokkan antara bukti pembelian tersebut dengan formulir permintaan barang yang telah diajukan, apabila cocok ambil bukti jika tidak sesuai lakukan konfirmasi ke supplier.

iii. Melakukan pembayaran atas dasar bukti pembelian barang dengan cara transfer ke rekening supplier atau memberikan cek atau uang tunai.

b. Dokumen yang digunakan

Dokumen yang digunakan oleh PT. Alfa Global Indonesia adalah Bukti kas keluar,

Kwitansi, Dokumen pendukung

c. Catatan akuntansi yang digunakan

i. pengajuan dana

ii. pengeluaran biaya-biaya

d. Fungsi yang terkait 

i. all devision
ii. kasir
iii. supplier

e. Unsur pengendalian intern pengeluaran kas

sistem pengendalian intern dalam sistem pengeluaran kas yang diterapkan oleh PT. Alfa

Global Indonesia adalah sebagai berikut:

i. Otoritas :

1) Adanya struktru organisasi yang terpisah

2) Transaksi pengeluaran kas dilakukan oleh kasir sejak awal sampai akhir

ii. Prosedur pencatatan

Pengeluaran ekstren menggunakan bilyet giro atas nama

iii. Praktek yang sehat

pencocokan kas dilakukan setiap hari dan diketahui oleh bagian keuangan.

f. Bagian alir sistem akuntansi pengeluaran kas pada PT. Alfa Global Indonesia

Alur pegeluaran kas pada PT. Alfa Global Indonesia akan digambarkan dalam bentuk bagan alir ata flowchart. Adapun bagan alir atau flowchart dari pengeluaran kas pada PT.

Alfa Global Indonesia adalah sebagai berikut :

4. Transaksi Pengeluaran kas

a. Prosedur pengeluaran kas pada PT. Alfa Global Indonesia

i. Alur pengeluaran uang kas dimulai dari transaksi pembelian tunai, pembayaran utang, dan pembayaran biaya-biaya.

ii. Menerima formulir permintaan barang atau jasa dan melampirkan bukti invoice/faktur pembelian yang dibawah atau diberikan oleh supplier untuk kemudian dicocokkan antara bukti pembelian tersebut dengan formulir permintaan barang yang telah diajukan, apabila cocok ambil bukti jika tidak sesuai lakukan konfirmasi ke supplier. Melakukan pembayaran atas dasar bukti pembelian barang dengan cara

\section{Gambar. 3. Flowchard pengeluaran kas PT.}

\section{Alfa Global Indonesia}

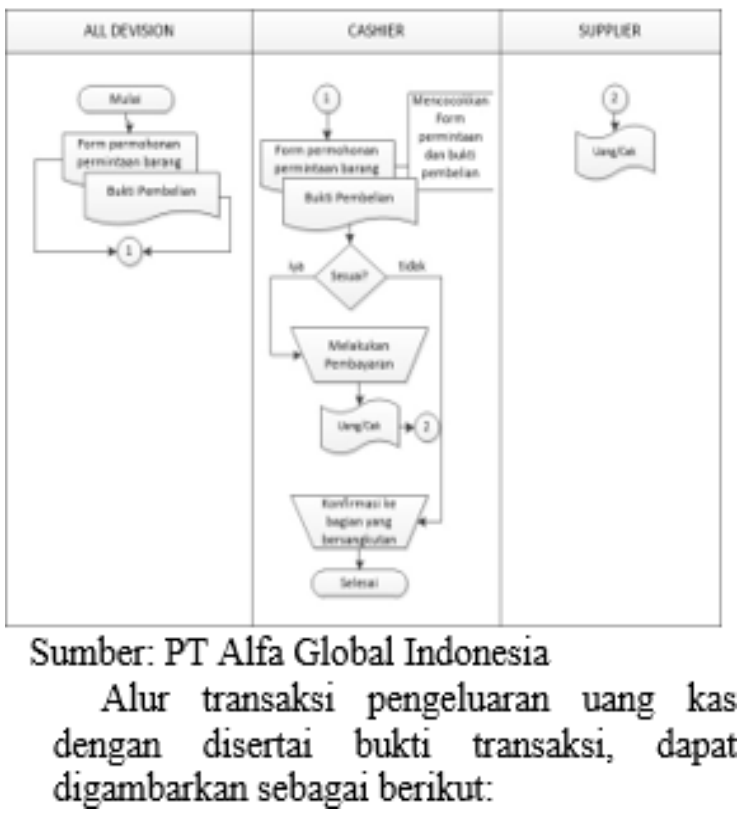

b. Dokumen yang digunakan, adapun dokumen yang digunakan dalam traksaksi pengeluaran kas adalah :

i. Bukti kas keluar 
Formulir ini yang digunakan PT. Alfa Global Indonesia untuk pengeluaran uang, baik melalui kas maupun bank.

ii. Kwitansi

Dokumen ini merupakan bukti pengeluaran uang yang terdiri dari 3 rangkap

iii. Dokumen pendukung

Dokumen lain yang digunakan sebagai pendukung BKK biasanya berupa pengajuan dana dan pengeluaran biaya-biaya.

c. Fungsi yang terkait dalam tranksaksi pengeluaran kas adalah :

i. fungsi all devision

Semua devisi bisa mengajukan permintaan dana kas tunai dengan cara menunjukkan dokumen pendukung terlebih dahulu kepada kasir

ii. fungsi cashier

Bagian ini bertanggung jawab atas pengelolan dana kas kecil dan

mempertanggung jawabkannya ke bagian keuangan dan pembukuan.

iii. fungsi supplier

Bagian ini bertanggung jawab untuk mencatat dan membukukan seIuruh transaksi pengeluaran kas dan menyusun laporan keuangan secara periodic.

d. Catatan akuntansi yang digunakan dalam transaksi pengeluaran kas adalah :

i. Pengajuan dana

ii. Pengeluaran biaya-biaya

1. Kelebihan sistem akuntansi pengeluaran kas pada perusahaan PT.Alfa Global Indonesia yaitu :

a. Prosedur yang membentuk sistem akuntansi pengeluaran kas : setiap transaksi pengeluaran menggunakan 3 metode yaitu cek, kas kecil dan via transfer.

b. Dokumen yang digunakan : setiap dokumen yang digunakan berangkap 3, rangkap 1 untuk pelanggan dan ragkap 2 untuk Customer Service. dan rangkap 3 untuk kasir, Sehingga dapat mencegah kecurangan.

c. Catatan yang digunakan : pencatatan yang dilakukan yaitu pengajuan data atas pengeluaran kas yang terjadi pada periode tertentu dan pengeluaran biaya-biaya untuk membayar transaksi-transaksi dalam pengeluaran kas

d. Fungsi yang terkait : Dalam pelaksanaan pengeluaran kas telah melibatkan beberapa bagian yang terkait untuk melaksanakan seIuruh transaksi keuangan yang terjadi dalam kegiatan operasi perusahaan selama periode tertentu.

e. Pengendalian intern : adanya pencocokan ulang (stock opname) yang dilakukan setiap pengeluaran dan diketahui oleh bagian keuangan atau pembukuan apabila ya, maka dilakukan proses pengeluaran kas. Apabila tidak, maka dikembalikan kepada calon supplier.

2. Kekurangan system akuntansi pengeluaran kas pada PT Alfa Global Indonesia yaitu :

a. Prosedur pengeluaran kas : pengeluaran kas secara tunai diambil dari saldo kas kasir sedangkan kas tersebut berasal dari penghasilan polis dan penghasilan lainnya secara tunai. Padahal dalam standar akuntansi tidak diperkenankan pengeluaran kas dari sumber tersebut.

b. Catatan yang digunakan : masih kurangnya catatan yang digunakan dalam pengeluaran kas sehingga perlu adanya pengeluaran kas

c. Fungsi pengendalian intern : Belum di bentuk bagian pemeriksaan intern untuk mengawasi pengeluaran kas secara periodic maupun mendesak. Bagian pemeriksaan intern diharapkan pengawasan dan pemeriksaan terhadap dana kas lebih terjamin kebenarannya.

\section{PENUTUP}

Berdasarkan Hasil penelitian dan pembahasan yang telah diuraikan pada babsebelumnya, tentang sistem akuntansi penerimaan dan pengeluaran kas pada PT Alfa Global Indonesia, maka dapat diambil kesimpulan sebagai berikut: 
1. Pada PT Alfa Global Indonesia secara keseluruhan dokumen yang digunakan sudah baik, secara control internal dokumen yang digunakan dapat dipakai dan dipertanggungjawabkan

2. Jaringan prosedur yang membentuk siste penerimaan dan pengeluaran kas pada PT Alfa Global Indonesia yaitu kas, permintaan dan pertanggung jawaban penerimaan dan pengeluaran kas

3. Harus dilakukan pengawasan ketat, pemeriksaan, penyesuaian dan pengecekan rutin dikarenakan rawan terjadi penyalahgunaan, kecurangan atau pencurian uang kas perusahaan

Berdasarkan Hasil penelitian dan analisis data maka dapat diberikan beberapa saran untuk Perusahaan yaitu :

Untuk peneliti selanjutnya, diharapkan melakukan analisis lebih mendalam menganai sistem akuntansi penerimaan dan pengeluaran kas di perusahaan lain dan dapat mengembangkan penelitian lainnya mengenai sistem akuntansi penerimaan dan pengeluaran kas.

\section{DAFTAR PUSTAKA}

Diana, A., Setiawati, L (2017) Akuntansi Keuangan menengah. Yogyakarta : CV Andi Offset (Penerbit Andi)

Harahap, S.S (2015) Teori Akuntansi. Jakarta:Rajawali Pers

Hery.(2016). Sistem Akuntansi edisi 4.Jakarta: Salemba Empat

Kusmiyati, N. (2018). Analisis system akuntansi pengeluaran kas pada PT. BPR PMU.Bandung:Jurnal Festival riseti lmiah manajemen akuntansi

Mahsina ., Lestari, T., Susriningsih (2018), Analisis Sistem Informasi Akuntansi Pengeluaran Kas Untuk Meningkatkan Pengendalian Intern PT. Kumala Wandira. Surabaya:Jurnal

Muliasari, N, A ., (2012), Analisis Siklus Pengeluaran Kas Pada PT. ABC. Depok: jurnal

Mulyadi, (2016), Sistem Akuntansi, Edisi Empat.Jakarta:Salemba empat

Puspita., (2015).Sistem akuntansi pengeluaran kas pada koperasi jasa keuangan syariah BMT Mubarokah.Semarang:Jurnal

Sadeli, L, M (2015) Dasar-dasar akuntansi. Jakarta:Bumi Aksara

Sari, P, S, T., Effendi, R., Meirasa, F (2014). Analisis Siklus pengeluaran kas pada CV starindo Shoes.Palembang:Jurnal

Siagian, S., (2018).Sistem Akuntansi Penerimaan dan Pengeluaran Kas Pada PT. Pegadaian (persero) Cabang Medan Utama. Medan:jurnal

Syarifuddin, (2019). Analisis Rasio Laporan Arus Kas Untuk Mengukur Kinerja Keuangan Pada PT. Karya Mandiri Surya Sejahtera Makassar: Jurnal Akmen. https://ejurnal.stienobel-indonesia.ac.id/index.php/akmen/article/view/668

Tanjung, T, U (2018). Sistem akuntansi pengeluaran kas pada perusahaan sequis life. Medan:Jurnal

Yusuf, M. (2014).Metode Penelitian Kuantitatif, Kualitatif, Dan Penelitian Gabungan. Jakarta:Prenada Media Group 